\title{
Determinants of Higher Institution Choice by Agriculture Undergraduate Students in Botswana
}

\author{
Moakofhi Kago Moakofhi* Oratile Leteane Tawona Vanessa Phiri \\ Department of Basic Sciences, Botswana University of Agriculture and Natural Resources, Private Bag 0027, \\ Sebele, Gaborone, Botswana.
}

\begin{abstract}
In this study, authors explored major factors that undergraduate students in Botswana consider vital in influencing their higher education institution choice decisions. It was based on a survey of 300 admitted students at the Botswana University of Agriculture and Natural Resources, to which $91.33 \%$ (274/300) of the sample responded. Data was collected using a questionnaire and analysed by coding and using Microsoft Excel package. Results show that the choice decision is based on a number of factors, with the main factors being location of the institution, availability of relevant study programmes, institutional reputation and how the institution marketing and advertise itself to potential students. The findings may have important implications for an institution's positioning in the competitive student recruitment market, and for re-evaluating marketing and advertising strategies. Recommendations are made on the basis of the main findings.
\end{abstract}

Keywords: higher education, higher education institution, undergraduate, choice decision, BUAN.

DOI: $10.7176 / \mathrm{JEP} / 10-18-07$

Publication date:June $30^{\text {th }} 2019$

\section{Introduction}

Botswana is a developing country which has seen a huge growth in the number of higher education institutions in recent years. This has led to a reduction in numbers of students who are sent abroad to pursue higher education training. This rise in the number of local institutions has created a greater menu for students to pick institutions of their own choices considering their needs and conveniences, more especially since students consider higher education institutions as service providers where they can purchase education (Boke, 2003). Botswana University of Agriculture and Natural Resources is one of the institutions in such a menu. The university offers training in agriculture and agriculture related programmes and it is adjacent to the capital city Gaborone. In recent years the enrolment of the university has been inconsistent, as shown in Table 1 and Figure 1 , therefore raising eyebrows as to why there is no consistency in enrolment patterns.

It is not yet quite clear as to which factors students in Botswana consider the most when choosing an institution to enrol with. Thus, it was imperative to study important factors that influence students' higher education institution choice decisions. The higher education institution choice is a decision influenced by a number of demographic, economic, social, political, and institutional factors (Ming, 2010). According to Lin (2007) different types of students choose to attend certain universities on the basis of one or more factors that link directly to their characteristics and needs. Major factors cited in the literature that influence higher education institution choice are: the advice of parents and friends, academic reputation of the institution, availability of the desired programme, availability of financial aid, cost of attending the institution, and the location of the institution. However, the relative importance of these factors is largely determined by the characteristics of the student and the types of the university as stated by Discenza, Ferguson and Wisner (2005).

Table 1: Enrolment at BUAN for the past 5 academic years

\begin{tabular}{|c|c|}
\hline Academic Year & Emmolment \\
\hline $2012 / 2013$ & 1523 \\
\hline $2013 / 2014$ & 1405 \\
\hline $2014 / 2015$ & 1236 \\
\hline $2015 / 2016$ & 1415 \\
\hline $2016 / 2017$ & 1384 \\
\hline
\end{tabular}

Depicted graphically, BUAN's inconsistent enrolment patterns is shown in the figure below. 


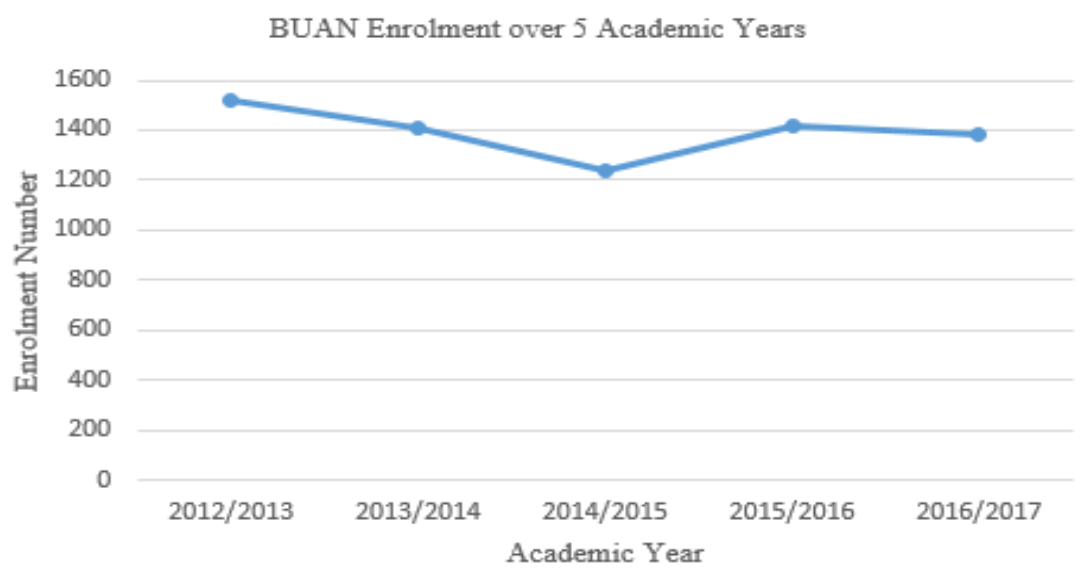

Figure 1: BUAN Enrolment Over 5 Academic Years

\section{Literature Review}

Much of the work on institutional choice decision come from the United States, Asia and some parts of Europe. These studies have identified common choice decision influencing factors such as institution's reputation, socioeconomic status, institution's location and employment and career opportunities (Briggs, 2006). For example, in their study on progression to higher education in Australia, Robinson and Bornholt (2007) found that choice decision greatly depends on family background, students' demographics, moves between learning environments, institution's policies and values, standards and assessments and expertise of faculty. Foskett and Hemsley-Brown (2002) see this variety of factors being problematic to evaluate, even for prospective students with access to quality information.

There are several related studies reporting that the influence of family, friends and peers plays a significant role on students' choice of higher education. Kusumawati (2013) identified five factors that influence Indonesian undergraduate students in choosing a higher education institution as parents' influence, job prospects, cost, institution's reputation and location. Family and peer influence was also found to be a determinant in choosing a higher education institution by New Zealand and United States undergraduate students (Ford, Joseph and Joseph, 1999). Wagner and Fard (2009) concluded the same for Malaysian undergraduate students. Parents' attitude was also identified by Jafari and Aliesmaili (2013) as a major factors that influence student to choose a higher education institution. According to Soutar and Turner (2002), friends and relatives' recommendations are "push" factors in motivating a higher education institution choice for students.

Several studies also show a positive relationship between an institution's academic programmes and students' choice decision for higher education institution. A study conducted by bin Yusof et al. (2008) revealed that availability of a required programme is considered an important attribute for first year university students in choosing a higher education institution in Malaysia. This was confirmed by Ming (2010) who in his framework on the institution factors that influence Malaysian students' college choice decision found availability of an academic programme to be one of the independent variables for such a choice. A study among undergraduate students in Sheffield in the United Kingdom also indicated that programme availability is one of the major factors in choosing a higher education institution (Price et al., 2003). In their study, Ford, Joseph and Joseph (1999) also found programme availability to have influenced New Zealand and United States undergraduate students to choose an institution of higher learning. This is the same in Australia as reported by Soutar and Turner (2002).

Other studies such as Ford, Joseph and Joseph (1999), Gray et al. (2003), Briggs (2006), Keling (2006), Ming (2010) and Kusumawati (2013), have shown institutional image and reputation as being a major influence on college choice. Franklin (2008) asserts that the reputation of an institution where the degree is earned is associated with that person throughout their life. Ming (2010) identifies college reputation as one of the fixed college characteristics that prospective students consider when choosing an institution to do their undergraduate studies at. Reputation for a higher education institution's academic quality was found to be one of the criteria used by bright, prospective students when choosing a college or university. The findings of a survey in the northeast of Scotland concluded that the most important attribute in choice is academic reputation (Gibbons-Wood and Lange, 1998). This shows the existence of a positive relationship between an institution's reputation and higher education institution choice decision.

According to Connor et al. (1999), although the most influential factor for Scottish undergraduate applicants to a higher education institution is being offered the right course, employment prospects, academic support facilities, location, image and reputation were other factors considered influential. Price et al. (2003) 
showed that in the UK, undergraduate students value availability of facilities such as computers, accommodation and library facilities when deciding on which institution to attend. Manoku (2015) found that Albanian undergraduate students rate educational facilities as having been influential in their decision to choose a university. Community college students also consider educational facilities as one of the major factors in their selection of a college (Absher and Crawford, 1996). This study therefore hypothesised that educational facilities have a significant influence on higher education institution choice decision for undergraduate students.

Other studies show cost-related issues as a significant predictor that influences higher education institution choice decision. Foskett, Roberts and Maringe (2006) conclude that economic factors such as course fees and accommodation costs are influencers in decision making of UK students for a university. Kusumawati (2013) reports that in Indonesia, undergraduate students identified cost, reputation, proximity, job prospects and parents as the five most important factors in their choice of higher education institution. Cost was also reported to be a significant factor by New Zealand undergraduate students in choosing a higher education institution (Ford, Joseph and Joseph, 1999). Ming (2010) developed a framework that shows cost and availability of financial aid as some of the institutional factors that a college choice decision is based upon. Price et al. (2003) see cost as a factor that encourages student to consider choosing a higher education institution that is close to home.

Other important factors such as: advertising (Hossler, 1990; Sabir et al., 2013), location (Price at al., 2003; Briggs, 2006; Absher and Crawford, 1996), employment opportunities (Paulsen, 2001; Moogan, Baron and Harris, 1999; Foskett, Roberts and Maringe, 2006; Sabir et al., 2013) and visits by high education institution's representatives (Ford, Joseph and Joseph, 1999; Manuko, 2015) have been found to influence students in choosing a college or university to attend. Thus, the authors hypothesise that a positive significant relationship exists between each of these factors and higher education institution choice decision.

\section{Survey Method}

The overall study objective was to come up with information on factors that influence Botswana undergraduate students' higher education institution decision choices. Therefore, a paper-based questionnaire was used to collect data from the study's test subjects, who were BUAN undergraduate students. In order to reduce the measurement error, the questionnaire was developed as follows: First, a pre-test of the questionnaire was done. The main goal of the pre-test was to improve the content of the measuring items, hence the questionnaire was given to two BUAN lecturers from, one from Statistics Unit and another one from the Educational Technology Unit, to improve face and content validity. From feedback gotten from the pre-test, wording was refined for some few items. Next stage, a pilot test of the study was performed with 15 BUAN students who were not part of the sample. The main purpose of the pilot test was to empirically check whether or not the questionnaire had accuracy or precision. The test re-test procedure of reliability measurement was used. In this procedure, the same instrument was administered on two different occasions to the same individual and the responses correlated. The pilot test results confirmed a solid reliability for all measurement items. The questionnaire had both open and closed ended questions. A total of 25 closed questions sort rankings of agreement on a standard five-point Likert scale defined as "Strongly Agree", "Agree", "Neutral", "Disagree" and "Strongly Disagree". These categories were scored from 1 to 5 respectively. The questionnaire had three sections: section A which mainly focused on demographic characteristics of the participants such as gender, age, and entry level, programme of study, home village, high school attended; section $\mathrm{B}$ assessed factors affecting students' choice of institution; section $\mathrm{C}$ investigated if students would recommend BUAN to anyone.

From a population of 1384 undergraduate students at BUAN, a sample of 300 (75 each from level 100 to level 400) students was used. To get this sample size, a sample size calculator from Creative Research Systems was used (https://www.surveysystem.com/sscalc.htm\#one) with a confidence level of $95 \%$ and confidence interval of 5 . This sample represents $21.68 \%$ of the total study population. A simple random sampling without replacement technique was used to select the 75 students from each level. This technique allows the researchers to decide who to sample based on the problem under study. The researchers sought the permission from Dean of Faculty of Agriculture and that of the research participants to administer questionnaires. Questionnaires were self-distributed by researchers and participants completed them. The participants were made aware of the voluntariness of their participation in the study and assured of confidentiality of the data they provided. They were asked not to write anything on the questionnaires that would reveal their identities. That helped to create a free platform for deliberation without fear or favour.

Three hundred (300) copies of the questionnaire were issued and upon completion two hundred and seventy four (274) were collected. Twenty six (26) were never gained back due to various reasons from participants. To avoid unnecessary loss of questionnaires participants were given 15 minutes to complete them since questions were short and simplified. A few students were given questionnaires to complete overnight, and 26 were not returned, bringing response rate to $91.33 \%$. All the questionnaires that were returned were deemed useful for analysis because there were no cases of missing data. After data was collected, it was coded and analysed using Microsoft Excel 2013. To analyse demographics cumulative percentages were used whereas for how students 
came to know about BUAN and what compelled them to choose programmes they are enrolled in, statistics such frequencies, means and the spread of data through standard deviations were used. Data was summarised in tables for easy understanding.

\section{Overall Findings}

Data was tabulated and analysed and results were interpreted using percentages and descriptive scales.

\subsection{Demographic Data}

Table 2: Profiles of the participants

\begin{tabular}{|c|c|c|c|}
\hline \multicolumn{2}{|c|}{ Characteristic } & Frequency & Percentage (\%) \\
\hline \multirow{2}{*}{ Gender } & Male & 161 & 58.76 \\
& Female & 113 & 41.24 \\
\hline \multirow{3}{*}{ Age } & & & 5.84 \\
& Under 19 & 16 & 78.83 \\
& $19-25$ & 216 & 8.39 \\
& $26-32$ & 13 & 4.74 \\
& $33-39$ & 6 & 2.19 \\
\hline \multirow{2}{*}{ Type of Entry } & Above 39 & & \\
& & 23 & 8.39 \\
& In-service & 251 & \\
\hline \multirow{3}{*}{ Field of Study } & Pre-service & 54 & 19.71 \\
& & 72 & 26.28 \\
& AEE & 57 & 20.80 \\
& AEL & 37 & 13.50 \\
& ASP & 37 & 13.50 \\
& AG & 17 & 6.20 \\
\hline & CSP & & \\
\hline & FST & 14 & 3.11 \\
& & 100 & 7.66 \\
& North & 21 & 50.73 \\
\hline
\end{tabular}

Table 2 gives information about participants' demographic profiles. It shows that responses were received from 161 males and 113 females, giving $58.76 \%$ and $41.24 \%$ respectively. Majority of the participants were in the age range $19-25$ years old and fewest in the age group of above 39 years old. These two age cohorts were represented by $78.83 \%$ and $2.19 \%$ respectively. Some students came to university straight from senior secondary schools (pre-service) and represented $91.61 \%$ of participants. Those who came to work to university to upgrade their levels of qualifications (in-service) represented $8.39 \%$ of participants. Table 2 also gives study fields from which participants were enrolled in. Undergraduate programmes available at BUAN are in broad fields of Crop Science and Production (CSP), Economics, Education and Extension (AEE), Agricultural Engineering and Land planning (AEL), Animal Science and Production (ASP), Food Science and Technology (FST) and General Agriculture The largest share of participants was from AEL with $26.28 \%$ while the lowest was FST with $6.20 \%$. The regions from where participants were attending their high schools are also shown in Table 2. South Central is leading with $50.73 \%$ of participants and the least was North with $5.11 \%$ of participants coming from this region Thus, according to Table 1, a typical undergraduate student at BUAN is a male of 19 to 25 years, who came straight from a senior secondary school in the South central region of Botswana to pursue a study programme from the Agricultural Engineering and Land Planning domain. 


\subsection{Research Questions}

Table 3: Marketing tool

\begin{tabular}{|c|c|c|c|c|c|c|c|c|}
\hline \multirow[b]{2}{*}{ Item } & \multirow[b]{2}{*}{ Mean } & \multirow{2}{*}{$\begin{array}{l}\text { Standard } \\
\text { Deviation }\end{array}$} & \multicolumn{5}{|c|}{ Response \% } & \multirow[b]{2}{*}{ Scale } \\
\hline & & & $\begin{array}{l}\text { Strongly } \\
\text { Agree }\end{array}$ & Agree & Neutral & Disagree & $\begin{array}{l}\text { Strongly } \\
\text { Disagree }\end{array}$ & \\
\hline Television & 3.5839 & 1.1930 & 9.12 & 8.76 & 19.34 & 40.15 & 22.63 & Disagree \\
\hline Radio & 4.0474 & 1.0206 & 3.28 & 7.66 & 6.93 & 45.26 & 36.86 & Disagree \\
\hline Newspaper & 2.1131 & 1.1184 & 31.02 & 46.35 & 9.49 & 6.57 & 6.57 & Agree \\
\hline Internet & 3.6825 & 1.0850 & 5.11 & 8.76 & 22.63 & 39.78 & 23.72 & Disagree \\
\hline $\begin{array}{l}\text { BUAN Rep } \\
\text { Visits }\end{array}$ & 3.9197 & 1.1646 & 5.47 & 10.22 & 8.39 & 38.69 & 37.23 & Disagree \\
\hline $\begin{array}{l}\text { Career } \\
\text { Fairs }\end{array}$ & 3.7190 & 1.2773 & 9.21 & 12.77 & 6.20 & 40.88 & 31.02 & Disagree \\
\hline
\end{tabular}

Table 3 shows that majority of students came to know BUAN and its programmes of study through newspapers. $77.37 \%$ of the participants both strongly agree and agree that this is the tool that they consulted to know about BUAN whereas other tools of marketing the university were not as widely consulted.

Table 4: Decision influence

\begin{tabular}{|l|c|c|c|c|c|c|c|c|}
\hline \multirow{2}{*}{ Item } & \multirow{2}{*}{ Mean } & \multirow{2}{*}{$\begin{array}{c}\text { Standard } \\
\text { Deviation }\end{array}$} & $\begin{array}{c}\text { Strongly } \\
\text { Agree }\end{array}$ & Agree & Neutral & Disagree & $\begin{array}{c}\text { Strongly } \\
\text { Disagree }\end{array}$ & \multirow{2}{*}{ Scale } \\
\hline $\begin{array}{l}\text { Family } \\
\text { influence }\end{array}$ & 3.6022 & 1.3199 & 11.31 & 11.68 & 11.68 & 36.13 & 29.20 & Disagree \\
\hline $\begin{array}{l}\text { Friends } \\
\text { influence }\end{array}$ & 3.6314 & 1.2750 & 9.12 & 11.68 & 16.42 & 32.48 & 30.29 & Disagree \\
\hline Self-decision & 1.9489 & 0.9632 & 35.40 & 45.62 & 9.85 & 6.93 & 2.19 & Agree \\
\hline
\end{tabular}

From Table 4 above, it can be seen that friends and family played little or no role in a participant' decision to choose a tertiary institution to enrol with. A high number of participants, $81.02 \%$, indicated that they made the decision on their own.

Table 5: Programmes offered

\begin{tabular}{|c|c|c|c|c|c|c|c|c|}
\hline \multirow[b]{2}{*}{ Item } & \multirow[b]{2}{*}{ Mean } & \multirow{2}{*}{$\begin{array}{l}\text { Standard } \\
\text { Deviation }\end{array}$} & \multicolumn{5}{|c|}{ Response \% } & \multirow[b]{2}{*}{ Scale } \\
\hline & & & $\begin{array}{c}\text { Strongly } \\
\text { Agree }\end{array}$ & Agree & Neutral & Disagree & $\begin{array}{l}\text { Strongly } \\
\text { Disagree }\end{array}$ & \\
\hline $\begin{array}{l}\text { Programme } \\
\text { relevance }\end{array}$ & 2.1095 & 1.0940 & 31.39 & 44.53 & 10.95 & 8.03 & 5.11 & Agree \\
\hline $\begin{array}{l}\text { Programme } \\
\text { variety }\end{array}$ & 2.1423 & 1.0681 & 27.00 & 48.91 & 13.50 & 4.01 & 6.57 & Agree \\
\hline
\end{tabular}

Table 5 indicates that most of the students found programmes offered relevant and have variety to choose from.

Table 6: Reputation of BUAN

\begin{tabular}{|c|c|c|c|c|c|c|c|c|}
\hline \multirow[b]{2}{*}{ Item } & \multirow[b]{2}{*}{ Mean } & \multirow{2}{*}{$\begin{array}{l}\text { Standard } \\
\text { Deviation }\end{array}$} & \multicolumn{5}{|c|}{ Response \% } & \multirow[b]{2}{*}{ Scale } \\
\hline & & & $\begin{array}{c}\text { Strongly } \\
\text { Agree }\end{array}$ & Agree & Neutral & Disagree & $\begin{array}{l}\text { Strongly } \\
\text { Disagree }\end{array}$ & \\
\hline $\begin{array}{l}\text { Good } \\
\text { assessment }\end{array}$ & 3.0949 & 1.2573 & 12.04 & 19.71 & 33.58 & 16.06 & 18.61 & Neutral \\
\hline $\begin{array}{l}\text { Cases of } \\
\text { corruption }\end{array}$ & 3.0584 & 1.1340 & 9.49 & 17.15 & 47.08 & 10.58 & 15.70 & Neutral \\
\hline $\begin{array}{l}\text { Professional } \\
\text { relationships }\end{array}$ & 2.4854 & 1.2050 & 20.80 & 40.51 & 16.42 & 13.87 & 8.39 & Agree \\
\hline
\end{tabular}

The results in Table 6 show that participants were neutral on whether their decision to enrol with BUAN 
was based on the university's reputation on good assessment and no cases of corruption. However, they agreed that their decision was based on the reputation of the university when it came to professional relationships between students and lecturers. This is shown by a low mean value of 2.4854 .

Table 7: Facilities and their usage

\begin{tabular}{|c|c|c|c|c|c|c|c|c|}
\hline \multirow[b]{2}{*}{ Item } & \multirow[b]{2}{*}{ Mean } & \multirow[b]{2}{*}{$\begin{array}{l}\text { Standard } \\
\text { Deviation }\end{array}$} & \multicolumn{5}{|c|}{ Response \% } & \multirow[b]{2}{*}{ Scale } \\
\hline & & & $\begin{array}{c}\text { Strongly } \\
\text { Agree }\end{array}$ & Agree & Neutral & Disagree & $\begin{array}{l}\text { Strongly } \\
\text { Disagree }\end{array}$ & \\
\hline $\begin{array}{l}\text { Facilities } \\
\text { and staffing }\end{array}$ & 2.8394 & 1.1142 & 14.96 & 17.15 & 45.99 & 12.77 & 9.12 & Neutral \\
\hline $\begin{array}{l}\text { Equipped } \\
\text { lecture halls }\end{array}$ & 3.0657 & 1.0941 & 9.85 & 12.77 & 52.55 & 10.58 & 14.23 & Neutral \\
\hline $\begin{array}{l}\text { Access to } \\
\text { facilities }\end{array}$ & 3.0839 & 1.2390 & 12.04 & 17.52 & 39.42 & 12.04 & 18.98 & Neutral \\
\hline
\end{tabular}

The results in Table 7 indicate that students remained neutral on issues of facilities and their usage.

Table 8: Cost implication

\begin{tabular}{|l|c|c|c|c|c|c|c|c|}
\hline \multirow{2}{*}{ Item } & \multirow{2}{*}{ Mean } & \multirow{2}{*}{$\begin{array}{c}\text { Standard } \\
\text { Deviation }\end{array}$} & $\begin{array}{c}\text { Strongly } \\
\text { Agree }\end{array}$ & Agree & Neutral & Disagree & $\begin{array}{c}\text { Strongly } \\
\text { Disagree }\end{array}$ & Scale \\
\hline $\begin{array}{l}\text { Low cost for } \\
\text { self } \\
\text { sponsorship }\end{array}$ & 3.8029 & 1.2275 & 8.03 & 10.95 & 5.84 & 43.07 & 32.12 & Disagree \\
\hline $\begin{array}{l}\text { Financial } \\
\text { awards }\end{array}$ & 3.7701 & 1.2173 & 6.20 & 15.33 & 4.74 & 42.70 & 31.02 & Disagree \\
\hline $\begin{array}{l}\text { Adequate } \\
\text { living } \\
\text { allowance }\end{array}$ & 4.2226 & 1.1018 & 5.47 & 4.74 & 4.74 & 32.12 & 52.92 & $\begin{array}{l}\text { Strongly } \\
\text { Disagree }\end{array}$ \\
\hline
\end{tabular}

Table 8 indicates that costs are too high and there are no financials awards for students. It also shows that participants strongly feel that personal living allowance (from government) for students is not sufficient for their up-keep, hence it was never a positive factor in their decision to choose to study at BUAN. This is shown by a high mean value of 4.2226 as $52.92 \%$ of the participants strongly disagreed that the student living allowance from government was adequate.

Table 9: Employment opportunities

\begin{tabular}{|c|c|c|c|c|c|c|c|c|}
\hline \multirow[b]{2}{*}{ Item } & \multirow[b]{2}{*}{ Mean } & \multirow[b]{2}{*}{$\begin{array}{l}\text { Standard } \\
\text { Deviation }\end{array}$} & \multicolumn{5}{|c|}{ Response \% } & \multirow[b]{2}{*}{ Scale } \\
\hline & & & $\begin{array}{c}\text { Strongly } \\
\text { Agree }\end{array}$ & Agree & Neutral & Disagree & $\begin{array}{l}\text { Strongly } \\
\text { Disagree }\end{array}$ & \\
\hline $\begin{array}{l}\text { Employment } \\
\text { opportunities }\end{array}$ & 3.8029 & 1.0152 & 4.38 & 9.49 & 8.39 & 56.93 & 20.80 & Disagree \\
\hline $\begin{array}{l}\text { Market for } \\
\text { programme }\end{array}$ & 2.9088 & 1.1653 & 15.33 & 17.15 & 38.32 & 19.71 & 9.49 & Neutral \\
\hline $\begin{array}{l}\text { Self- } \\
\text { employment }\end{array}$ & 2.2263 & 1.1860 & 30.66 & 38.69 & 16.06 & 6.57 & 8.03 & Agree \\
\hline
\end{tabular}

From Table 9 it can be seen that participants' decision to study at BUAN was not influenced by availability of employment opportunities. $77.73 \%$ of participants both disagree and strongly disagree that there are employment opportunities available after completion of the study programmes. However, their belief that there are opportunities for self-employment formed part of their decision to enrol with BUAN. $69.62 \%$ of the participants both agree and strongly agree that programmes available at BUAN offers graduates chances for selfemployment.

\section{Discussions}

This study provides evidence about factors that influence higher education institution choice decision for Botswana undergraduate students.

The majority of participants were males with $58.76 \%$ and females occupied $41.24 \%$ which might be due to the fact that there are more males than females in the institution. Most of the participants were of ages between 19 and 25. This age range is normally for people who come straight from senior secondary schools, hence are pre-service students. Only $8.39 \%$ of the participants were in-service students, which can be explained by the fact that the government of Botswana temporarily suspended sending workers for further training and development. Study results show that most of the students came from South Central and North Central regions with $50.73 \%$ and $36.50 \%$ respectively. North and South regions comprised the remaining minority of $5.11 \%$ and $7.66 \%$ 
respectively. The latter regions are very far from Botswana University of Agriculture and Natural Resources and thus there is a high chance that they could not get enough or relevant information about the institution. The findings affirm research by Sevier (1994) that college or university location can be a major factor for a potential student's decision to apply and enrol.

The results also show that the most participants got information about the university from newspapers than any other advertising tool. Some potential students might have never laid their hands on newspapers or they never reach their places as they stay in far and rural areas. There is very little being done to advertise the institution on other forms of media like radio, television, social media and updates on the Internet hence the low intake. In their findings, Hossler (1990) discovered that advertising is a significant predictor that influences tertiary institution choice decision. It also indicated that some senior secondary schools were never visited by BUAN representatives hence students from those schools hardly had exposure to career fairs. This proves results by Manoku (2015) that visits to high schools by college admissions representatives were rated as an extremely effective influence for prospective students. BUAN is known to be a reputable institution with no cases of corruption reported. The institution is also shown to exhibit good working professional relationship between lecturers and students as shown in Table 6. This might be due to well defined and established assessment criteria. Keling (2007) also stated that the most influential factor that students will evaluate in selecting their choice of institution was reputation of the institution.

When it comes to facilities, students indicated that there is not much to say as results showed that they remained neutral. The neutrality might be due to the fact some facilities are well equipped whereas some need improvement. Even though the results showed that participants remained neutral in the issue of learner to lecturer ratio, some cited the use of part-time lecturers as a setback. Some also indicated that there was overpopulation in some classes. Most of the students indicated that they like the programmes they were enrolled in. They also said that there was variety to choose from and programmes were relevant to their career paths. That proved study conducted by bin Yusof et al. (2008) who found that availability of the required programme is a very important element for first year university students to choose a particular higher education institution. In Botswana most of the tertiary institution students are sponsored by government and that means all who have credits that qualify them to enrol with an institution of choice may apply for sponsorship. The tuition fees are not a burden for individuals but participants reported living allowances to be very low. The institution was also shown to lack financial rewards for students which may also be a contributing factor to low enrolment. Ismail (2009) also indicated that students who receive financial aid awards are more likely to enter college.

The majority of students showed that the programmes they are enrolled in have low employment prospects and they aimed at being self-employed. The findings by Sevier (1994) were that students are interested in outcomes and are influenced by what graduates are doing, what graduate schools they attend and contributions that they are making to society. That meant that students might have role models in the agribusiness that influenced their choice of tertiary institution. The participants were asked an open ended question of whether they would recommend anyone to enrol with BUAN, and asked to support their answers with reasons. $71.2 \%$ participants answered in the affirmative whereas the remaining $28.8 \%$ said they would not recommend anyone to study at BUAN. Those who said they would recommend someone to enrol with BUAN gave some reasons, amongst them:

\section{- Self-employment opportunities}

- $\quad$ Variety of programmes for skills and knowledge acquisition.

- $\quad$ Being armed and sharing information with other farmers

- $\quad$ Creating jobs for others

- $\quad$ Being part of poverty eradication campaign by improving productivity and output.

For those who said they could not recommend anyone to study at BUAN, they gave only one reason being that of lack of formal jobs for graduates.

\section{Conclusions}

The purpose of study was to find out the most important and relevant factors which students consider when choosing tertiary institution to enrol with. Different factors were discussed and results could be useful to the university, parents and potential students. It can be concluded that higher education agriculture institutions in Botswana have higher proportion of pre-service students whose choice of an institution is based on them wanting to be self-employed rather than being job seekers. Therefore, employment prospects was found not to be one of the factors agriculture undergraduate students considered when choosing to study at a higher education institution. Institutional facilities and cost-issues are not major factors agriculture undergraduate students consider important when choosing an institution of higher learning. Agriculture undergraduate students are not influenced by their parents, peers and friends when deciding on which higher education institution to enrol with. The major factors that influenced agriculture undergraduate students in making a decision about which higher education institution to attend were location, institution's high ethical standards and good reputation, availability 
of relevant academic programmes and relevant institutional promotion and advertising.

\section{Implications}

Implications for BUAN is to come up with programmes tailor-made for students to assist them in their endeavour of self-employment. The university will have to come up with ways of reaching potential students, such as incorporating relevant Web 2.0 services like social media, blogs and other social website tools into its promotional marketing packages and strategies in order to attract prospective students who do not access traditional media such as newspapers and radio. There could also be road shows to raise awareness in both the old and the young so that they know what is happening in the institution. It would also be of vital importance that students' stay in the university is made affordable and enjoyable by having financial rewards and awards to recognise their achievements. Students are not satisfied with some of the facilities provided by the university, hence there is a need for these facilities to be taken care of either by regular maintenance or upgrading. Students must be able do most the activities online e.g. registration, getting examination results and other submissions, hence a need for a learning management system to be implemented.

\section{Limitations}

As is normally the case with empirical research, this study has some limitations that should be considered when interpreting its results. The study used a small sample from only one faculty of the university, that of Agriculture, hence the generalizability of its findings is limited. Other faculties are bot used as they are not yet fully functional. Therefore conclusions made from this study might need to be confirmed by further research for the whole university and at other higher education institutions in Botswana. Findings report about factors with implications to only undergraduate students market, hence further research can cover the graduate market. Another limitation is that the study did not cover the decision making abilities of students, hence further research can be done in this area to augment the current study. Finally, the study was only based on a public higher education institution and did not examine what obtains at a private institution, hence might not be fully representative of higher education institutions in Botswana. Thus, future studies can look at what influences student choice decision to enrol at a private higher education institution and further examine differences of student decisions for public and private higher education institutions. All these limitations notwithstanding, the results of this study should be a very good starting point for research on factors that influence students to choose particular universities to study with in Botswana.

\section{References}

Absher, K. and Crawford, G., 1996. Marketing the community college starts with understanding students' perspectives. Community College Review, 23(4), pp.59-68.

bin Yusof, M., binti Ahmad, S.N.B., bin Mohamed Tajudin, M. and Ravindran, R., 2008. A study of factors influencing the selection of a higher education institution. UNITAR e-journal, 4(2), pp.27-40.

Bok, D., 2009. Universities in the marketplace: The commercialization of higher education (Vol. 39). Princeton University Press.

Briggs, S., 2006. An exploratory study of the factors influencing undergraduate student choice: the case of higher education in Scotland. Studies in Higher Education, 31(6), pp.705-722.

Connor, H., Burton, R., Pearson, R., Pollard, E. and Regan, J., 1999. Making the right choice: how students choose universities and colleges. London: CVCP.

Discenza, R., Ferguson, J.M. and Wisner, R., 1985. Marketing higher education: using a situation analysis to identify prospective student needs in today's competitive environment. NASPA journal, 22(4), pp.18-25.

Ford, J.B., Joseph, M. and Joseph, B., 1999. Importance-performance analysis as a strategic tool for service marketers: the case of service quality perceptions of business students in New Zealand and the USA. Journal of Services marketing, 13(2), pp.171-186.

Foskett, N., Roberts, D. and Maringe, F., 2006. Changing fee regimes and their impact on student attitudes to higher education. Southampton: University of Southampton.

Foskett, N. and Hemsley-Brown, J., 2002. Choosing futures. Routledge.

Franklin, P., 2008. The reputation of your college and its importance. [http://ezinearticles.com/?The-Reputationof-Your-College-and-its-Importance\&id=970913]] Retrieved: September 26, 2016.

Gibbons-Wood, D. and Lange, T., 1998. Accessing higher education: the views of prospective students in the Northeast of Scotland. Aberdeen: Centre for International Labour Market Studies, The Robert Gordon University.

Gray, B.J., Shyan Fam, K. and Llanes, V.A., 2003. Branding universities in Asian markets. Journal of Product \& Brand Management, 12(2), pp.108-120.

Hossler, D., 1990. The Strategic Management of College Enrollments. Jossey-Bass Inc., 350 Sansome St., San Francisco, CA 94104 
Ismail, N., 2009. Mediating effect of information satisfaction on college choice. Oxford Business \& Economics Conference Program. UK.

Jafari, J. and Aliesmaili, A., 2013. Factors influencing the selection of a university by high school students. Journal of Basic and Applied Science Research, 3(1), pp.696-703.

Keling, S.B.A., 2006. Institutional factors attracting students to Malaysian institutions of higher learning. International Review of Business Research Papers, 2(1), pp.46-64.

Kusumawati, A., 2013. A qualitative study of the factors influencing student choice: The case of public university in Indonesia. Journal of Basic and Applied Scientific Research, 3(1), pp.314-327.

Lin, L., 1997. What are student education and educational related needs?. Marketing and research today, 25(3), pp.199-212.

Manoku, E., 2015. Factors that influence university choice of Albanian students. European Scientific Journal, ESJ, 11(16)

Ming, J.S.K., 2010. Institutional factors influencing students' college choice decision in Malaysia: A conceptual framework. International Journal of Business and Social Science, 1(3).

Moogan, Y.J., Baron, S. and Harris, K., 1999. Decision-making behaviour of potential higher education students. Higher Education Quarterly, 53(3), pp.211-228.

Paulsen, M.B., 2001. Going to College: How Social, Economic, and Educational Factors Influence the Decisions Students Make.

Price, I.F., Matzdorf, F., Smith, L. and Agahi, H., 2003. The impact of facilities on student choice of university. Facilities, 21(10), pp.212-222.

Robinson, R.A. and Bornholt, L.J., 2007. Pathways Theory of Progression through Higher Education. Australian Journal of Educational \& Developmental Psychology, 7, pp.49-62.

Sabir, R.I., Ahmad, W., Ashraf, R.U. and Ahmad, N., 2013. Factors affecting university and course choice: A comparison of undergraduate engineering and business students in Central Punjab, Pakistan. Journal of Basic and Applied Scientific Research, 3(10), pp.298-305.

Sevier, R.A., 1994. Image Is Everything--Strategies for Measuring, Changing, and Maintaining Your Institution's Image. College and University, 69(2), pp.60-75.

Soutar, G.N. and Turner, J.P., 2002. Students' preferences for university: A conjoint analysis. International Journal of Educational Management, 16(1), pp.40-45.

Wagner, K. and Fard, P.Y., 2009. Factors influencing Malaysian students' intention to study at a higher educational institution. E-Leader Kuala Lumpur.

\section{Acknowledgments}

The authors declare that they have no conflicts of interest in the study. They would like to thank lecturers who helped with validating the questionnaire. They would also like to thank all students who took part in this study. 